\title{
Karakteristik Fisikokimia Tepung Ubi Banggai dan Aplikasinya Dalam Beras Analog
}

\section{Physicochemical Characteristics of Banggai Yams Flour and Their Application in Analogue Rice}

\author{
Aini Auliana Amar, Feri Kusnandar*, dan Slamet Budijanto \\ Departemen Ilmu dan Teknologi Pangan, Fakultas Teknologi Pertanian, Institut Pertanian Bogor, Bogor
}

\begin{abstract}
Banggai yam (Dioscorea sp) has many varieties, which is locally cultivated and consumed by people in Banggai, Central Sulawesi. Banggai yam can be processed into flour and applied as an ingredient in analogue rice. This study aimed to evaluate the physical and chemical composition, total phenol and antioxidant activity of banggai yam flours, and the physical properties, total phenol and antioxidant activity of their analogue rice. Five varieties of banggai yams (Harum, Banggai, Pasus, Doso, and Penus) were compared. Banggai yam flours were composed of moisture (12.21-12.74\%wb), ash (2.18$2.75 \% d b)$, protein $(10.41-11.68 \% d b)$, fat $(1.05-3.38 \% d b)$, and carbohydrate $(83.22-85.77 \% \mathrm{db})$. All banggai flours had different color ( $L, a$, and $b$ values) intensities, and contained starch (65.38-68.40\% $\mathrm{db}$ ) with amylose content of 38.96-45.09\% (db). The total phenol ranged from 30.48-116.90 mg GAE/ $100 \mathrm{~g}$, and showed antioxidant activity (58.71-89.50\% inhibition). The pasting profile varied among five yam flours. The initial pasting temperatures of banggai yam flour were relatively high $\left(82.5-83.7^{\circ} \mathrm{C}\right)$. All banggai yam flour increased in viscosity up to a peak and experienced slight viscosity breakdown during the heating phase, as well as showed a setback viscosity during cooling phase. Rice analogue of yam flours made by extrusion technology had a relatively low bulk density $(0.47-0.56 \mathrm{~g} / \mathrm{mL})$, and required a long cooking time (7-9 minutes). The rice analog had different levels of total phenol and antioxidant activities. The level of total phenol and antioxidant activity of analogue rice from Harum yam showed the highest compared to those other analogue rice.
\end{abstract}

Keywords: antioxidant, analogue rice, Banggai yam, pasting profile, total phenol

\begin{abstract}
Abstrak. Ubi banggai (Dioscorea sp) memiliki banyak varietas, yang dibudidayakan secara lokal dan dikonsumsi oleh masyarakat Banggai di Sulawesi Tengah. Ubi banggai dapat diolah menjadi tepung dan diaplikasikan sebagai ingredien pangan dalam beras analog. Penelitian ini bertujuan untuk mengevaluasi karakteristik komposisi kimia, kadar total fenol dan aktivitas antioksidan dari tepung ubi banggai dan sifat fisik, kadar total fenol dan aktivitas antioksidan dari beras analog yang dihasilkan. Sebanyak lima varietas ubi banggai (Harum, Banggai, Pasus, Doso, dan Penus) digunakan dalam penelitian ini. Ubi banggai dari kelima varietas memiliki kadar air (12.21-12.74\% bb), kadar abu (2.18-2.75\% bk), kadar protein (10.41-11.68\% bk), kadar lemak (1.05-3.38\% bk), dan kadar karbohidrat (83.22-85.77\% bk). Kelima varietas tepung ubi banggai memiliki intensitas warna (nilai L, a dan b) yang berbeda dan mengandung pati cukup tinggi (65.38-68.40\% bk) dengan kadar amilosa 38.96-45.09\% (bk). Tepung ubi banggai memiliki total fenol berkisar 30.48-116.90 mg EAG/100 g, serta menunjukkan aktivitas antioksidan (58.71-89.50\% inhibisi). Profil pasta pati dari kelima ubi banggai bervariasi. Suhu awal pasta pati relatif tinggi $\left(82.5-83.7^{\circ} \mathrm{C}\right)$. Semua tepung banggai mengalami peningkatan viskositas hingga mencapai maksimum dan sedikit mengalami penurunan viskositas (breakdown) selama fase pemanasan, serta mengalami viskositas setback selama fase pendinginan. Beras analog ubi banggai yang dibuat dengan teknologi ekstrusi memiliki densitas kamba yang relatif rendah $(0.47-0.56 \mathrm{~g} / \mathrm{mL})$, dan memerlukan waktu pemasakan yang cukup lama (7-9 menit). Beras analog ubi banggai memiliki kadar totar fenol dan aktivitas antioksidan yang berbeda. Kadar total fenol dan aktivitas antioksidan beras analog dari ubi Harum paling tinggi dibandingkan beras analog lainnya.
\end{abstract}

Kata kunci: antioksidan, beras analog, profil pasta pati, total fenol, ubi banggai

\footnotetext{
Aplikasi Praktis. Penelitian ini memberikan informasi mengenai potensi ubi banggai yang dapat diolah menjadi tepung dan dimanfaatkan sebagai ingredien pangan baru untuk pengolahan pangan. Ubi banggai memiliki karakteristik yang unik berdasarkan kandungan amilosanya yang tinggi, dan memiliki kandungan komponen bioaktif (fenol) dan aktivitas antioksidan. Tepung ubi banggai dapat diaplikasikan sebagai ingredien fungsional dalam produksi beras analog.
}

*Korespondensi: fkusnandar@apps.ipb.ac.id 


\section{PENDAHULUAN}

Ubi banggai merupakan jenis ubi-ubian lokal yang banyak dibudidayakan di Kabupaten Banggai, Banggai Laut dan Banggai Kepulauan di Provinsi Sulawesi Tengah. Ubi banggai termasuk ke dalam famili Dioscoreae dan genus Dioscorea. Yalindua (2014) melaporkan terdapat sebanyak 38 varietas ubi banggai yang dibudidayakan dan dikonsumsi masyarakat Banggai, di antaranya varietas Baku Harum, Baku Pasus, Baku Doso dan Baku Penus. Menurut Yusuf et al. (2015), ubi banggai dengan varietas katu'u, pusus dan memeila diproduksi dengan rata-rata 10-30 ton/ha. Setiap veriates ubi banggai memiliki bentuk dan warna yang khas. Ubi banggai ada yang berwarna putih dengan bentuk silindris dan pangkal meruncing (seperti varietas butun), ungu tua dengan bentuk silindris dan pangkal meruncing (seperti varietas Doso), kekuningan dengan bentuk bulat (seperti varietas tau), campuran putih ungu dengan bentuk silindris dan pangkal runcing (seperti varietas paupau ateno), dan kecokelatan dengan bentuk silindris dan pangkal runcing (seperti varietas lembet) (Yalindua 2014). Kekhasan lain dari ubi banggai adalah mengeluarkan cairan lendir ketika dikupas dan direndam dalam air.

Warna ubi banggai yang bervariasi dapat disebabkan oleh adanya senyawa fenol yang diketahui memiliki aktivitas antioksidan. Ubi banggai mengandung karbohidrat yang tinggi, yaitu mengandung $63.31 \%$ pati, $6.66 \%$ protein dan $0.64 \%$ lemak, sehingga berpotensi untuk dimanfaatkan sebagai bahan pangan non beras (Ariesta, 2004). Penelitian yang lain dilaporkan bahwa esktrak pati ubi banggai mengandung pati $88.5 \%$ bk dengan kadar amilosa $60.29-62.88 \%$ bk dari total pati (Mutmainah, 2020). Hal ini menjadi kekhasan dari ubi banggai dibandingkan ubi yang lain. Ubi jalar mengandung karbohidrat $85.92 \%$ bk dengan kadar amilosa $30.30 \%$ bk (Retnaningtyas dan Putri, 2014),

Masyarakat Banggai Kepulauan mengonsumsi ubi banggai sebagai makanan pokok, yaitu diolah menjadi payot yang diproses dengan cara direbus, diparut, dibungkus daun pisang dan digoreng. Ubi banggai juga biasa diolah oleh masyarakat Kabupaten Banggai Kepulauan menjadi bubur bayi atau dimasak dengan santan kelapa dan garam yang disebut nalum. Adeningsih et al. (2015) mengembangkan bubur ubi banggai dari varietas baku makulolong dan baku pukus. Masyarakat Kabupaten Banggai Laut juga mengolah ubi banggai menjadi keripik.

Ubi banggai dapat ditepungkan dan dimanfaatkan sebagai ingredien pangan. Salah satu potensi aplikasinya adalah diolah menjadi tepung dan digunakan sebagai ingredien dalam pembuatan beras analog. Pengolahan beras analog dapat memanfaatkan berbagai macam sumber karbohidrat atau protein. Beras analog dapat diproses dari bahan baku ubi-ubian (singkong), sagu, bijibijian (jagung, kedelai, kacang hijau) dan serealia (Noviasari et al. 2017), sehingga dapat mendukung program diversifikasi pangan. Tepung umbi banggai dimanfaat- kan sebagai bahan baku pembuatan beras analog yang diharapkan dapat memberikan nilai tambah terhadap umbi lokal ini. Mutu fisik dan sensori, komposisi kimia dan keunggulan fungsional dari beras analog yang dihasilkan berbeda-beda yang dipengaruhi oleh jenis dan komposisi bahan utama, serta ingredien lain yang digunakan. Beras analog telah dikembangkan oleh peneliti sebelumnya dari berbagai jenis tepung ubi-ubian dan kacang-kacangan (Budi et al. 2013; Nurdjanah et al. 2014; Noviasari et al. 2015; Srihari et al. 2016; Budijanto et al. 2016; Noviasari et al. 2017; Kusnandar et al. 2020; Kurniasari et al. 2020). Pemanfaatan tepung ubi banggai sebagai bahan baku pembuatan beras analog belum dilaporkan. Demikian juga karakteristik tepung ubi banggai yang diperlukan sebagai informasi dasar untuk aplikasi dalam proses pengolahan pangan masih sangat terbatas.

Penelitian ini bertujuan untuk mengevaluasi karakteristik fisikokimia (komposisi kimia) dan fungsional (khususnya total fenol dan aktivitas antioksidan) dari tepung ubi banggai, dan sifat fisik dan sifat kimia (kadar air, total fenol dan aktivitas antioksidan) beras analog yang dihasilkan. Sebanyak lima varietas ubi banggai (Harum, Banggai, Pasus, Doso, dan Penus) digunakan dalam penelitian ini.

\section{BAHAN DAN METODE}

\section{Bahan}

Lima varietas ubi banggai (Harum, Banggai, Pasus, Doso, dan Penus) diperoleh dari petani di Kabupaten Banggai Laut Sulawesi Tengah (dipanen setelah delapan bulan masa tanam). Bahan lain yang digunakan dalam pembuatan beras analog (pati jagung dan gliserol monostearat (GMS) diperoleh dari pasar lokal di Bogor. Bahan kimia yang digunakan untuk analisis di antaranya sodium 1.2-naphthoquinone-4-sulfonate (Folin), 2.2diphenyl-1-picrylhydrazyl (DPPH), etanol (Merck, Jerman), metanol (Merck, Jerman), dietil eter (Merck, Jerman), gas nitrogen, standar amilosa, standar glukosa, DNS, iodin, akuades. Semua bahan kimia yang digunakan untuk analisis adalah analytical grade.

Peralatan utama yang digunakan dalam pembuatan beras analog adalah ekstruder ulir ganda (Berto BEX-DS 2256, Indonesia) dan oven. Peralatan analisis yang digunakan di antaranya adalah oven (Eyela NDO-400, Jepang), spektrofotometer UV-Vis (Genesys 150, AS), Lab Chromameter (CR-400 Minolta, AS), neraca analitik (Adventurer Ohaus, Cina), tanur (Nabertherm B180, Jerman), Rapid Visco Analyzer (RVA, Tecmaster, Newport Scientific, Australia), vortex, hand sentrifuge, penangas air, desikator, rangkaian alat soxhlet dan Kjeldhal, serta alat gelas yang umum digunakan di laboratorium kimia.

\section{Karakterisasi tepung ubi banggai}

Proses penepungan ubi banggai mengacu pada Eduardo et al. (2013). Ubi banggai dibersihkan, dikupas 
dan diparut dengan menggunakan parutan keripik. Hasil parutan direndam dalam air garam $30 \%$ selama 20 menit untuk menghilangkan lendir. Setelah dicuci, parutan ubi dikeringkan dalam oven $\left(60^{\circ} \mathrm{C}\right.$ selama 8 jam $)$, dan digiling halus dan diayak sehingga diperoleh tepung ubi banggai dengan ukuran 80 mesh. Sampel tepung banggai dikarakterisasi komposisi kimia (analisis proksimat, pati, amilosa, amilopektin dan total fenol), analisis fisik yang meliputi warna (metode Chromameter) dan profil pasta pati (metode RVA), serta aktivitas antioksidannya (metode DPPH). Analisis proksimat mencakup kadar air (metode oven), kadar abu (metode tanur), kadar protein kasar (metode Kjeldhal), kadar lemak (metode soxhlet) dengan mengacu metode AOAC (2005). Kadar total karbohidrat dihitung by difference.

\section{Karakterisasi beras analog ubi banggai}

Proses pembuatan beras analog mengacu pada metode Budijanto dan Yulianti (2012). Bahan yang digunakan dalam pembuatan beras analog adalah campuran dari ubi banggai dari masing-masing varietas (78\%), pati jagung (20\%), dan GMS (2\%). Ketiga bahan tersebut dicampurkan hingga merata, lalu ditambah air sebanyak $50 \%$ dari total bahan kering. Adonan basah kemudian dimasukan ke dalam alat ekstruder dengan suhu barrel di-set pada $75^{\circ} \mathrm{C}$ dan kecepatan auger 25.5 $\mathrm{Hz}$, screw $26.8 \mathrm{~Hz}$ dan cutter $33.8 \mathrm{~Hz}$. Selama proses ekstrusi ini terjadi proses pencampuran, shearing dan pencetakan melalui die. Ekstrudat basah kemudian dikeringkan dalam oven $\left(60^{\circ} \mathrm{C}, 3 \mathrm{jam}\right)$. Sampel beras analog kemudian dianalisis kadar air, total fenol, aktivitas antioksidan (persentase inhibisi), waktu pemasakan, densitas kamba dan bobot seribu butir.

\section{Analisis pati (Sani et al. 2014)}

Sampel tepung ubi banggai $(0.1 \mathrm{~g})$ ditambah $5 \mathrm{~mL}$ dietil eter, lalu divortex, disentrifusi selama 5 menit, dan disemprot dengan gas nitrogen hingga sampel kering. Sampel lalu ditambah $4 \mathrm{~mL}$ etanol $80 \%$, divortex dan disentrifusi lagi selama 5 menit. Perlakuan ini diulang sebanyak dua kali. Sisa etanol diuapkan dengan penangas air $\left(60-90^{\circ} \mathrm{C}\right)$. Sampel kemudian dihidrolisis dengan menambahkan $3 \mathrm{~mL} \mathrm{HCl} \mathrm{7 \%}$, lalu divortex dan dipanaskan di atas penangas air $\left(90^{\circ} \mathrm{C}\right)$ selama 2.5 jam (vortex dilakukan setiap 30 menit). Sampel kemudian dipindahkan ke dalam labu Erlenmeyer dan diatur pHnya menjadi $7.0 \pm 0.1$ dengan penambahan larutan $\mathrm{NaOH} 0.1 \mathrm{~N}$. Setelah disaring, larutan sampel ditepatkan volumenya dengan labu takar hingga $100 \mathrm{~mL}$.

Sebanyak $0.5 \mathrm{~mL}$ sampel kemudian ditambahkan $1.5 \mathrm{~mL}$ akuades dan $3 \mathrm{~mL}$ DNS, kemudian diinkubasi dalam air mendidih selama 10 menit, dan diukur absorbansinya dengan spektrofotometer UV-Vis pada panjang gelombang $540 \mathrm{~nm}$. Larutan standar glukosa (40, 60, 80, 100, 120 dan $140 \mathrm{mg} / \mathrm{L})$ digunakan untuk membuat kurva standar yang digunakan untuk menghitung konsentrasi glukosa pada sampel. Kadar pati dihitung dari konsentrasi glukosa dengan faktor konversi 0.9 (dinyatakan dalam persen berat kering).

\section{Analisis kadar amilosa dan amilopektin (AACC 1999)}

Sebanyak $0.1 \mathrm{~g}$ sampel tepung ubi banggai ditambah $1 \mathrm{~mL}$ etanol 95\%, divortex, dan ditambahkan $9 \mathrm{~mL}$ $\mathrm{NaOH} 1 \mathrm{~N}$. Setelah dibiarkan pada suhu ruang selama 10 menit, sampel dipanaskan di atas penangas air yang mendidih selama 30 menit dan divortex setiap 10 menit. Sampel kemudian dipindahkan secara kuantitatif ke dalam labu takar $100 \mathrm{~mL}$ dan ditepatkan volumenya, dan diukur dengan spektrofotrometer UV-Vis pada panjang gelombang $620 \mathrm{~nm}$. Standar yang adalah larutan standar amilosa (0.08; 0.016; 0.024; 0.032 dan $0.040 \mathrm{mg} / \mathrm{L}$. Konsentrasi amilosa dinyatakan dalam persen berat kering. Kadar amilopektin dihitung sebagai selisih antara kadar pati dengan kadar amilosa.

\section{Analisis total fenol (Kong et al. 2012)}

Sebanyak $0.5 \mathrm{~g}$ sampel ditambah $10 \mathrm{~mL}$ etanol $80 \%$, dipanaskan dalam penangas air bergoyang $\left(55^{\circ} \mathrm{C}, 3,5\right.$ jam), dan disentrifusi (3000 rpm, 10 menit). Larutan standar dibuat dengan membuat larutan induk dari asam galat dengan konsentrasi $100 \mathrm{mg} / \mathrm{L}$, kemudian diencerkan menjadi 50, 40, 30, 20, 10 dan 5 (mg/L). Sampel dan larutan standar kemudian diambil 0,4 mL dan ditambahkan $4 \mathrm{~mL} \mathrm{Na}_{2} \mathrm{CO}_{3} 2 \%$ dan $0.2 \mathrm{~mL}$ Folin $50 \%$. Selanjutnya sampel diinkubasi di tempat gelap selama 30 menit, lalu diukur absorbansinya pada panjang gelombang $750 \mathrm{~nm}$ dengan menggunakan spektofotometer UV-Vis. Total fenol dinyatakan dalam ekuivalen asam galat (mg EAG)/100 g.

\section{Analisis aktivitas antioksidan (Baba dan Malik 2015)}

Analisis aktivitas antioksidan dilakukan untuk sampel tepung ubi banggai dan beras analog dengan metode DPPH. Sebanyak $1.0 \mathrm{~g}$ sampel ditambahkan 10 $\mathrm{mL}$ metanol, lalu divortex dan didiamkan selama 24 jam. Sampel disentrifusi (3000 rpm, 10 menit). Sebanyak $0.2 \mathrm{~mL}$ filtrat sampel dimasukkan ke dalam tabung reaksi yang dibungkus dengan aluminium foil, lalu ditambah $3.8 \mathrm{~mL}$ larutan DPPH 25 ppm. Sampel diinkubasi selama 1 jam di tempat yang gelap dan diukur absorbansinya pada panjang gelombang $517 \mathrm{~nm}$ dengan spektofotometer UV-Vis. Kontrol yang digunakan adalah $0.2 \mathrm{~mL}$ metanol yang ditambah $3.8 \mathrm{~mL}$ larutan DPPH $25 \mathrm{mg} / \mathrm{L}$. Aktivitas antioksidan dinyatakan sebagai persentase inhibisi.

\section{Analisis profil pasta pati (Jiang et al. 2012)}

Analisis profil pasta pati dilakukan dengan menggunakan RVA. Sebanyak $2.5 \mathrm{~g}$ sampel (berat kering) ditambah $20 \mathrm{~mL}$ akuades. Sampel ditempatkan dalam instrumen untuk dianalisis berdasarkan siklus pemanasan dan pendinginan. Sampel dipanaskan pada suhu awal $50^{\circ} \mathrm{C}$ dan dinaikkan hingga $95^{\circ} \mathrm{C}$ dengan kecepatan $12^{\circ} \mathrm{C} /$ menit, dan dipertahankan pada suhu tersebut selama 2.5 menit. Sampel kemudian didinginkan dengan cara menurunkan suhu ke $50^{\circ} \mathrm{C}$ dengan kecepatan $12^{\circ} \mathrm{C} /$ menit dan dipertahankan selama dua menit. Parameter yang diperoleh dari pengukuran ini adalah suhu awal 
gelatinisasi, viskositas maksimum, viskositas breakdown, viskositas setback, dan viskositas akhir. Viskositas dinyatakan dalam $\mathrm{cP}$.

\section{Analisis warna (Kusnandar et al. 2017)}

Warna pati dianalisis dengan menggunakan Chromamometer CR-400/410. Instrumen dikalibrasi dengan menggunakan plat standar putih. Sampel beras analog diletakkan secara merata ke dalam cawan (granular materials attachment CR-A50), kemudian kepala optik ditempelkan pada sampel lalu dilakukan pengukuran. Parameter yang diukur adalah nilai L, a, dan b dan hasil pengukuran merupakan rata-rata dari tiga ulangan.

\section{Analisis bobot seribu butir (Hernawan dan Meylani 2008)}

Sebanyak 1000 butir sampel beras analog dipilih yang utuh dan memiliki ukuran panjang yang relatif sama, kemudian ditimbang. Bobot seribu butir dinyatakan dalam gram $(\mathrm{g})$.

\section{Densitas kamba (Singh et al. 2005)}

Sampel beras analog dimasukkan ke dalam gelas ukur, dipadatkan hingga mencapai $100 \mathrm{~mL}$ dan ditimbang. Densitas kamba dinyatakan dalam g/mL.

\section{Waktu pemasakan (Noviasari et al. 2013)}

Sampel beras analog dimasak dalam rice cooker dengan perbandingan air dan beras 1:1 (v:b). Air dimasak terlebih dahulu hingga mendidih kemudian beras analog dimasukkan dan dimasak hingga matang. Waktu pemasakan dihitung sejak beras analog dimasukkan hingga masak (sampai posisi memasak rice cooker off).

\section{Analisis data}

Data karakteristik tepung dan beras analog dianalisis dengan uji $\mathrm{t}$ dengan menggunakan SPSS version 22 untuk menentukan perbedaan antar sampel pada taraf siginifikansi 5\%. Uji korelasi Pearson menganalisis hubungan antar data parameter aktivitas antioksidan dan total fenol pada tingkat kepercayaan 5\%).

\section{HASIL DAN PEMBAHASAN}

\section{Karakteristik tepung ubi banggai}

Kelima ubi banggai memiliki warna yang berbeda, yaitu ubi Harum (putih ungu), ubi Banggai (putih kekuningan), ubi Pasus (putih), ubi Doso (ungu) dan ubi Penus (putih). Keragaman intensitas warna yang dimiliki kelima varietas tepung ubi banggai dapat dipengaruhi oleh pigmen warna yang terkandung di daging ubi banggai. Gambar 1 menunjukkan warna irisan dalam dari kelima ubi banggai yang digunakan dalam penelitian ini. Perbedaan warna kelima tepung ubi banggai ini bersesuaian dengan hasil pengukuran warna dengan Chromameter (Tabel 1). Tepung ubi Penus memiliki nilai L yang tertinggi jika dibandingkan dengan tepung varietas yang lainnya, yang menunjukkan ubi tersebut memiliki warna putih cerah. Tepung ubi Doso merupakan tepung yang memiliki nilai a paling tinggi yang sejalan dengan warna ungu dari ubinya. Tepung ubi Banggai memiliki nilai b yang tertinggi, yang sesuai dengan warna putih kekuningan dari ubinya.

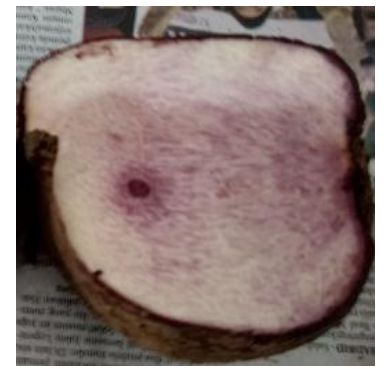

Ubi Harum

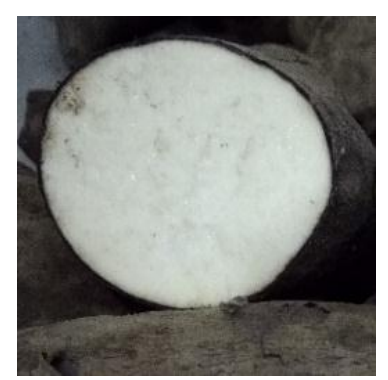

Ubi Pasus

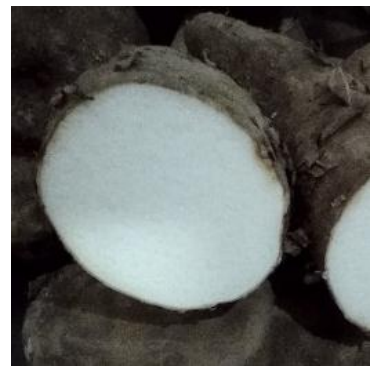

Ubi Banggai

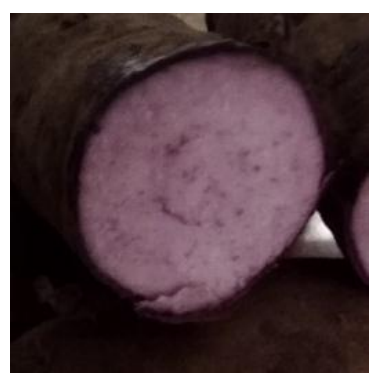

Ubi Doso

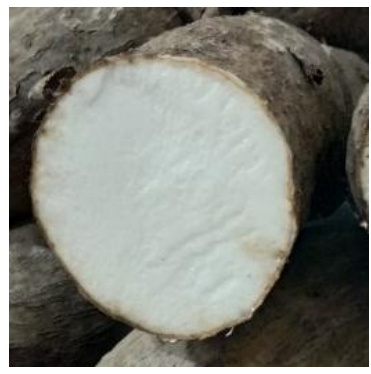

Ubi Penus

Gambar 1. Irisan dalam lima varietas ubi banggai

Tabel 1. Mutu warna tepung ubi banggai

\begin{tabular}{lccc}
\hline \multirow{2}{*}{ Varietas } & \multicolumn{3}{c}{ Parameter } \\
\cline { 2 - 4 } & $\mathbf{L}$ & $\mathbf{a}$ & $\mathbf{b}$ \\
\hline Ubi Harum & $73.27 \pm 0.22^{\mathrm{a}}$ & $3.66 \pm 0.07^{\mathrm{d}}$ & $7.92 \pm 0.07^{\mathrm{c}}$ \\
Ubi Banggai & $80.44 \pm 0.22^{\mathrm{b}}$ & $1.28 \pm 0.02^{\mathrm{b}}$ & $8.18 \pm 0.13^{\mathrm{a}}$ \\
Ubi Pasus & $78.74 \pm 0.44^{\mathrm{b}}$ & $1.43 \pm 0.01^{\mathrm{c}}$ & $6.99 \pm 0.06^{\mathrm{b}}$ \\
Ubi Doso & $72.49 \pm 0.08^{\mathrm{b}}$ & $5.44 \pm 0.05^{\mathrm{e}}$ & $2.15 \pm 0.02^{\mathrm{a}}$ \\
Ubi Penus & $81.53 \pm 0.04^{\mathrm{b}}$ & $1.01 \pm 0.03^{\mathrm{a}}$ & $6.91 \pm 0.02^{\mathrm{b}}$ \\
\hline
\end{tabular}

Keterangan: Nilai pada kolom yang sama diikuti huruf yang berbeda menunjukkan perbedaan yang nyata $(p<0.05)$

Komposisi kimia kelima tepung ubi banggai disajikan pada Tabel 2. Kelima varietas tepung memiliki kadar air dan abu yang relatif sama. Kadar lemak ubi banggai relatif rendah (1.05-3.38\%bk), namun relatif lebih tinggi dibandingkan ubi bentul $(0.31 \%$ bk) (Fidyasari et al. 2017). Kandungan protein tepung ubi banggai relatif tinggi, yaitu berkisar antara 10.41-11.68\% bk, dengan kandungan tertinggi ditunjukkan oleh tepung ubi Harum $(11.68 \%$ bk). Kadar protein ini lebih tinggi 
dibandingkan ubi-ubi lainnya, yaitu ubi bentul $(3.54 \%$ bk) (Fidyasari et al. 2017) dan ubi kayu (0.53-3.22\% bk) (Ariani et al. 2017). Kadar karbohidrat dari ubi banggai cukup tinggi, yaitu $83.22-85.77 \%$ bk, yang relatif lebih tinggi dibandingkan Dioscorea rotundata lain $(40.61 \%$ bk) (Alinnor dan Akalezi 2010). Kadar karbohidrat ubi banggai lebih rendah dibandingkan ubi bentul $(88.03 \%$ bk) (Fidyasari et al. 2017).

Komponen karbohidrat dari tepung ubi banggai terutama disusun oleh pati, yaitu berkisar antara 65.38$68.40 \%$ bk, yang relatif sama (Tabel 3). Kadar pati ini lebih rendah dibandingkan tepung dari ubi famili dioscoreae lain dari Jawa Timur, yaitu antara 79.27-86.68\% (bk) (Winarti dan Saputro 2013), namun lebih tinggi dibandingkan tepung singkong (19.13-24.49\%) (Ariani et al. 2017). Kadar amilosa dan amilopektin sebagai penyusun pati berbeda-beda (Tabel 3). Kadar amilosa tepung ubi banggai dari kelima varietas relatif tinggi, yaitu berkisar 38.96-45.09\%, sebaliknya kadar amilopektinnya relatif rendah. Kadar amilosa ubi Penus paling tinggi (45.99\% bk), sedangkan ubi Doso paling rendah $(38.96 \%$ bk). Kadar amilosa yang tinggi ini menjadi ciri khas yang dimiliki oleh ubi banggai yang tidak ditemui pada ubi-ubi lainnya. Sebagai perbandingan, kadar amilosa dari enam varietas famili Dioscoreae dari Jawa Timur hanya berkisar 7.48-18.98\% bk (Winarto dan Saputro 2013). Kadar amilosa yang tinggi ini mirip dengan tepung kacang hijau, yaitu 53.70-55.39\% bk (Triwitono et al. 2017). Tepung dengan kadar amilosa lebih dari $25 \%$ dikelompokkan sebagai tepung dengan amilosa tinggi (Zhong et al. 2018).

Tabel 3. Kadar pati, amilosa dan amilopektin tepung ubi banggai

\begin{tabular}{lccc}
\hline Varietas & Pati (\% bk) & $\begin{array}{c}\text { Amilosa (\% } \\
\text { bk) }\end{array}$ & $\begin{array}{c}\text { Amilopektin } \\
\text { (\% bk) }\end{array}$ \\
\hline Ubi Harum & $68.40 \pm 1.39^{\mathrm{a}}$ & $40.48 \pm 0.25^{\mathrm{b}}$ & $27.92 \pm 1.14^{\mathrm{c}}$ \\
Ubi Banggai & $68.13 \pm 0.43^{\mathrm{a}}$ & $43.13 \pm 0.14^{\mathrm{c}}$ & $25.00 \pm 0.29^{\mathrm{b}}$ \\
Ubi Pasus & $65.93 \pm 1.26^{\mathrm{a}}$ & $40.82 \pm 0.37^{\mathrm{b}}$ & $25.11 \pm 0.89^{\mathrm{b}}$ \\
Ubi Doso & $65.38 \pm 1.30^{\mathrm{a}}$ & $38.96 \pm 0.50^{\mathrm{a}}$ & $26.41 \pm 0.80^{\mathrm{bc}}$ \\
Ubi Penus & $66.87 \pm 1.05^{\mathrm{a}}$ & $45.09 \pm 0.30^{\mathrm{a}}$ & $21.77 \pm 1.35^{\mathrm{a}}$ \\
\hline
\end{tabular}

Keterangan: Nilai pada kolom yang sama diikuti huruf yang berbeda menunjukkan perbedaan yang nyata $(p<0.05)$

Tabel 4 menunjukkan kadar total fenol dari tepung ubi banggai. Kadar total fenol sangat bervariasi, yaitu berkisar 30.48-110.90 mg EAG/100 g. Kadar fenol tertinggi ditunjukkan oleh tepung ubi Harum (116.90 mg EAG/100 g), sedangkan yang terendah adalah ubi Penus (30.48 mg EAG/100g). Total fenol ini lebih rendah dibandingkan dengan famili dioscoreae yang berasal dari Filipina, yaitu varietas Daking (421.8 mg EAG/100 g bk), Shiket (231.5 mg EAG/100 g bk), Rapang-rapang (178.9 mg EAG/100 g bk) dan Highland Tugui (156.5 mg EAG/100 g bk). Khususnya untuk tepung ubi Harum, kadar total fenolnya lebih tinggi dibandingkan dengan varietas Lowland Tugui (112.4 mg EAG/100 g bk), Sampero (70.2 mg EAG/100 g) dan Kimabajo (69.9 mg EAG/100 g bk) (Cornago et al. 2011).

Tabel 4. Total fenol tepung ubi banggai

\begin{tabular}{lcc}
\multicolumn{1}{c}{ Varietas } & $\begin{array}{c}\text { Total Fenol } \mathbf{( m g} \\
\text { EAG/100 g bk) }\end{array}$ & $\begin{array}{c}\text { Aktivitas Antioksidan } \\
\text { (\% Inhibisi) }\end{array}$ \\
\hline Ubi Harum & $116.90 \pm 0.26^{\mathrm{a}}$ & $89,50 \pm 2,19^{\mathrm{c}}$ \\
Ubi Banggai & $31,51 \pm 0,02^{\mathrm{b}}$ & $40,30 \pm 4,26^{\mathrm{a}}$ \\
Ubi Pasus & $38.29 \pm 0.09^{\mathrm{b}}$ & $63.65 \pm 2.13^{\mathrm{b}}$ \\
Ubi Doso & $41.25 \pm 0.03^{\mathrm{b}}$ & $58.71 \pm 1.13^{\mathrm{b}}$ \\
Ubi Penus & $30.48 \pm 0.00^{\mathrm{b}}$ & $63.88 \pm 7.79^{\mathrm{b}}$ \\
\hline Keterangan: Nilai & pada kolom yang sama diikuti huruf yang
\end{tabular}

berbeda menunjukkan perbedaan yang nyata $(p<0.05)$

Aktivitas antioksidan dalam penelitian ini dinyatakan dengan persentase inhibisi yang menunjukkan kemampuan senyawa untuk bereaksi dengan senyawa radikal untuk membentuk senyawa netral (Dungir et al. 2012). Persentase inhibisi kelima varietas ubi banggai berkisar antara 40.30-89.50\% (Tabel 4). Kecenderungan aktivitas antioksidan ini berkorelasi positif ( $r=0.798$; $\mathrm{p}<0.05)$ dengan kadar total fenol, dengan aktivitas antioksidan cenderung lebih tinggi bila kadar total fenolnya tinggi. Persentase inhibisi tertinggi dimiliki oleh tepung ubi Harum (89.60\%), dan tepung ubi Harum juga memiliki total fenol tertinggi (116.90 mg EAG/100g bk). Senyawa fenol memiliki aktivitas antioksidan sebab memiliki gugus hidroksil yang tersubstitusi pada posisi orto dan para terhadap gugus -OH dan OR yang dapat bereaksi dengan radikal bebas (Marjoni et al. 2015).

Gambar 2 memperlihatkan profil pasta pati dari kelima varietas ubi banggai, dan parameter yang terukur disajikan pada Tabel 5. Tepung ubi Penus memiliki profil pasta pati paling tinggi, sedangkan ubi harum paling rendah. Suhu awal gelatinisasi cenderung tinggi $\left(82.5^{-} 83.7^{\circ} \mathrm{C}\right)$. Kecenderungan suhu awal gelatinisasi yang tinggi juga ditunjukkan oleh tepung-tepungan lain yang memiliki kadar amilosa yang relatif tinggi, seperti kacang hijau (Zou et al. 2019). Amilosa mampu membentuk ikatan hidrogen yang kuat, sehingga dibutuhkan energi yang tinggi untuk memutuskan ikatan hidrogen tersebut agar proses gelatinisasi pati terjadi (Martens et al. 2018).

Pati mengalami peningkatan viskositas hingga tercapai viskositas puncak, setelah mencapai suhu awal gelatinisasi. Viskositas puncak untuk setiap tepung ubi banggai berbeda-beda yang menunjukkan kemampuan gelatinisasi dari pati ubi banggai berbeda-beda. Tepung ubi Harum memiliki puncak viskositas terendah, sedangkan ubi Penus tertinggi (Tabel 5).

Tabel 2. Komposisi kimia tepung ubi banggai dari kelima varietas

\begin{tabular}{lccccc}
\hline \multicolumn{1}{c}{ Varietas } & Air $(\%$ bb) & Abu $(\%$ bk) & Protein $(\%$ bk) & Lemak (\% bk) & Karbohidrat (by difference) (\%bk) \\
\hline Ubi Harum & $12.21 \pm 0.44^{\mathrm{a}}$ & $2.71 \pm 0.54^{\mathrm{a}}$ & $11.68 \pm 1.31^{\mathrm{a}}$ & $0.75 \pm 0.01^{\mathrm{b}}$ & $84.84 \pm 1.30^{\mathrm{a}}$ \\
Ubi Banggai & $12.71 \pm 0.19^{\mathrm{a}}$ & $2.18 \pm 0.07^{\mathrm{a}}$ & $10.88 \pm 0.26^{\mathrm{a}}$ & $1.05 \pm 0.23^{\mathrm{ab}}$ & $85.77 \pm 0.86^{\mathrm{a}}$ \\
Ubi Pasus & $12.74 \pm 0.14^{\mathrm{a}}$ & $2.75 \pm 0.52^{\mathrm{a}}$ & $11.24 \pm 0.82^{\mathrm{a}}$ & $1.27 \pm 0.00^{\mathrm{ab}}$ & $84.62 \pm 0.66^{\mathrm{ab}}$ \\
Ubi Doso & $12.24 \pm 1.90^{\mathrm{a}}$ & $2.62 \pm 0.06^{\mathrm{a}}$ & $10.73 \pm 0.20^{\mathrm{a}}$ & $3.38 \pm 0.65^{\mathrm{ab}}$ & $83.22 \pm 2.14^{\mathrm{a}}$ \\
Ubi Penus & $12.61 \pm 0.15^{\mathrm{a}}$ & $2.63 \pm 0.34^{\mathrm{a}}$ & $10.41 \pm 0.46^{\mathrm{a}}$ & $2.52 \pm 1.56^{\mathrm{a}}$ & $84.32 \pm 1.48^{\mathrm{a}}$ \\
\hline
\end{tabular}

Nilai pada kolom yang sama diikuti huruf yang berbeda menunjukkan perbedaan yang nyata $(p<0.05)$ 


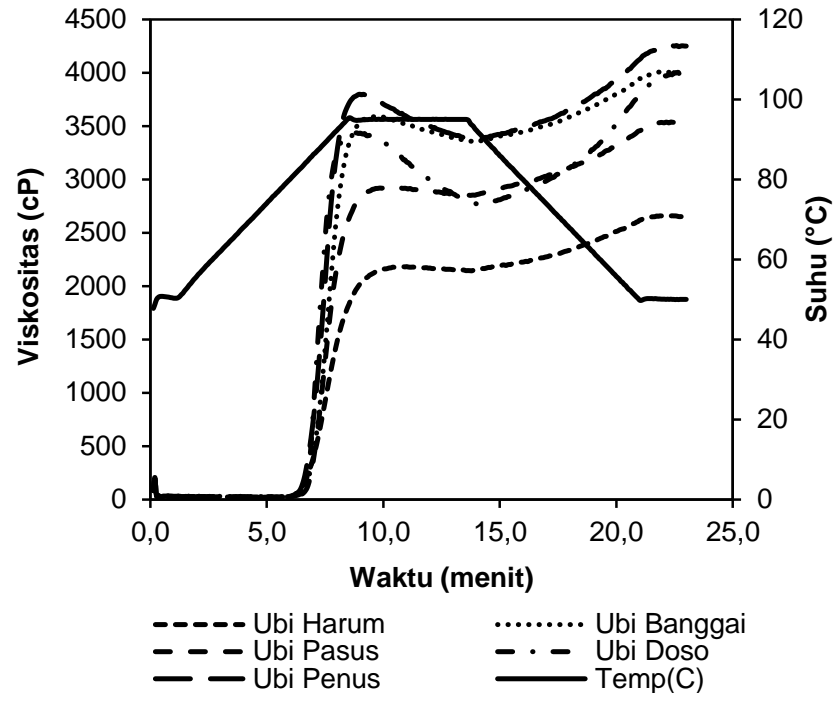

Gambar 2. Profil pasta pati tepung ubi banggai

Profil pasta pati mengalami sedikit penurunan viskositas (breakdown), setelah viskositas puncak tercapai. Kelima tepung ubi banggai menunjukkan fenomena pola gelatinisasi yang hampir sama. Ubi harum memiliki viskositas breakdown yang rendah $(39.5 \mathrm{cP})$, sedangkan ubi Doso dan ubi Penus memiliki viskositas breakdown yang tinggi $(666.0 \mathrm{cP})$. Hal ini menunjukkan ubi Harum cenderung memiliki ketahanan panas yang relatif tinggi dibandingkan ubi lainnya (Tabel 5). Penurunan viskositas ini relatif rendah dibandingkan ubi-ubian lain, seperti ubi jalar (3093.50 cP) (Sunyoto et al. 2016), yang menjadi keunikan yang dimiliki oleh ubi banggai.

Tabel 5. Profil pasta pati tepung ubi banggai

\begin{tabular}{lccccc}
\hline \multicolumn{1}{c}{ Parameter } & \multicolumn{5}{c}{ Tepung Ubi Banggai } \\
\cline { 2 - 6 } & Harum & Banggai & Pasus & Doso & Penus \\
\hline $\begin{array}{l}\text { Suhu awal } \\
\text { gelatinisasi }\left({ }^{\circ} \mathrm{C}\right)\end{array}$ & $82.6^{\mathrm{a}}$ & $83.3^{\mathrm{b}}$ & $83.7^{\mathrm{c}}$ & $83.3^{\mathrm{b}}$ & $82.5^{\mathrm{a}}$ \\
$\begin{array}{l}\text { Viskositas } \\
\text { maksimum (cP) }\end{array}$ & $2206.5^{\mathrm{a}}$ & $3596.0^{\mathrm{d}}$ & $2848.5^{\mathrm{b}}$ & $3436.0^{\mathrm{c}}$ & $3755.5^{\mathrm{e}}$ \\
$\begin{array}{l}\text { Viskositas } \\
\text { breakdown (cP) }\end{array}$ & $39.5^{\mathrm{a}}$ & $230.5^{\mathrm{a}}$ & $191.5^{\mathrm{a}}$ & $666.0^{\mathrm{b}}$ & $589.5^{\mathrm{b}}$ \\
$\begin{array}{l}\text { Viskositas akhir } \\
(\mathrm{cP})\end{array}$ & $2678.5^{\mathrm{a}}$ & $4004.0^{\mathrm{c}}$ & $3410.0^{\mathrm{b}}$ & $3997.0^{\mathrm{c}} 4162.0^{\mathrm{c}}$ \\
$\begin{array}{l}\text { Viskositas setback } \\
(\mathrm{cP})\end{array}$ & $511.5^{\mathrm{a}}$ & $638.5^{\mathrm{ab}}$ & $753.0^{\mathrm{b}}$ & $1226.0^{\mathrm{c}}$ & $996.0^{\mathrm{c}}$ \\
$\begin{array}{l}\text { Keterangan: Nilai pada baris yang sama diikuti huruf yang berbeda } \\
\text { menunjukkan perbedaan yang nyata }(\mathrm{p}<0.05)\end{array}$ &
\end{tabular}

Pada fase pendinginan, pasta tepung ubi banggai cenderung kembali meningkat atau mengalami viskositas setback. Tepung ubi Doso memiliki nilai viskositas setback yang tertinggi $(1226.0 \mathrm{cP})$, sedangkan ubi Harum yang terendah (511.5 cP) (Tabel 5). Viskositas setback yang tinggi menunjukkan kecenderungan pati membentuk gel yang disebabkan oleh terbentuknya ikatan-ikatan hidrogen antar senyawa penyusun pati. Pati yang memiliki viskositas setback yang tinggi cenderung mengalami retrogradasi dan sineresis, terutama disebabkan oleh kandungan amilosanya yang tinggi yang menyerupai kandungan amilosa pada tepung kacang hijau (Zou et al. 2019; Triwitono et al. 2017). Tepung kacang hijau memiliki sifat retrogradasi dan sineresis yang tinggi yang berkorelasi dengan kandungan amilosanya (Whistler et al. 2012). Tepung ubi Penus memiliki nilai viskositas akhir (end viscosity) tertinggi $(4162.0 \mathrm{cP})$, sedangkan tepung ubi harum yang terendah (2678.5 cP) (Tabel 5). Kandungan amilosa yang tinggi dari ubi banggai berperan dalam memberikan profil pasta pati yang unik dari kelima varietas ubi banggai. Hal ini juga dikonfirmasi oleh penelitian yang dilaporkan oleh Mutmainah (2020).

\section{Karakteristik beras analog}

Pada proses pembuatan beras analog, bahan campuran yang digunakan ditambahkan air yang cukup tinggi dan dan kemudian dimasukan ke dalam ekstruder ulir ganda dengan suhu barrel yang tidak terlalu tinggi $\left(75^{\circ} \mathrm{C}\right)$. Pada proses tersebut, maka ekstrudat yang dihasilkan tidak mengalami puffing. Beras analog yang dihasilkan dari proses tersebut dapat dilihat pada Gambar 3. Menurut Rodríguez-Miranda et al. (2012), kadar air bahan yang tinggi dapat mencegah terjadinya pengembangan ekstrudat setelah melewati die. Beras analog yang dikeringkan memiliki kadar air yang relatif sama (7.16-8.43\%bb) (Tabel 6). Beras analog yang dihasilkan dari ubi banggai memiliki warna yang beragam, yaitu ungu gelap (ubi Harum), kekuningan (ubi Banggai), kecoklatan (ubi Pasus), ungu muda (ubi Doso) dan putih tulang (ubi Penus).

Bobot seribu butir beras analog dari ubi banggai dari kelima varietas berkisar antara 10.10-15.71 g (Tabel 6). Bobot ini lebih rendah dibandingkan dengan beras analog dari sorgum dengan penambahan rempah campuran (19.19-19.69\%) dan beras sosoh (16.97\%) (Rasyid et al. 2016). Bobot setiap butir dari beras analog dapat dipengaruhi oleh proses pencetakan, yaitu kecepatan ulir dan kecepatan pemotong pada ekstruder saat proses ektruksi. Jika kecepatan ulir dan pemotong dikurangi maka beras analog yang dihasilkan semakin besar, dan sebaliknya.

Densitas kamba menunjukkan volume yang dibutuhkan untuk mencapai berat tertentu (Noviasari et al. 2017). Densitas kamba dari suatu bahan pangan merupakan salah satu indikator yang perlu diketahui karena sangat berperan dalam proses pengemasan, penyimpanan dan transportasi. Nilai densitas kamba yang besar membutuhkan tempat yang lebih kecil dan sebaliknya. Jika dikaitkan dengan kesehatan maka produk pangan yang memiliki densitas kamba yang rendah menimbulkan efek cepat kenyang sehingga baik dikonsumsi bagi orang-orang yang sedang diet (Setiawati et al. 2014). Densitas kamba beras analog dari ubi banggai berkisar 0.47-0.56 g/mL (Tabel 6). Perbedaan densitas kamba antara beras analog dapat disebabkan oleh pembentukan partikel beras analog yang tidak seragam selama proses ekstrusi yang mempengaruhi porositas dan pembentukan rongga (Sede et al. 2015). Namun demikian, hasil densitas kamba ini cenderung mendekati densitas kamba beras analog yang ditambahkan tepung rumput laut dan tepung mocaf (0.53-0.57 g/mL) (Agusman et al. 2014) dan dari campuran tepung jagung dan kacang merah 
(0.52 g/mL) (Aini et al. 2019). Noviasari et al. (2017) menyatakan bahwa bobot seribu butir dari beras analog juga terkait dengan parameter densitas kamba dari beras analog. Pengeringan dapat menyebabkan beras analog kehilangan air, sehingga menyebabkan matriksnya menjadi lebih banyak kering dan poros yang dapat menurunkan densitas kamba (Noviasari et al. 2017).

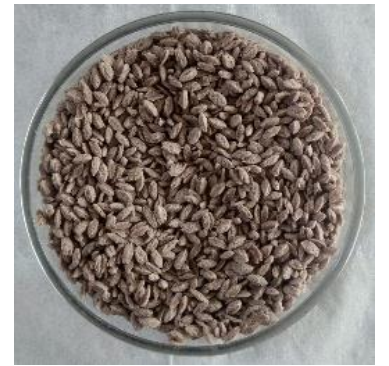

A

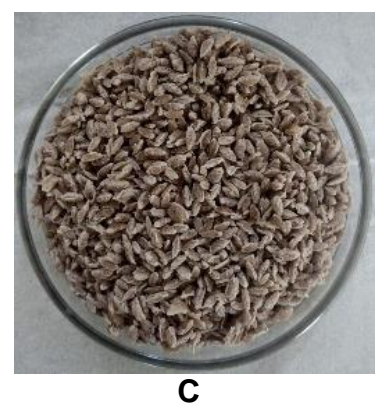

C

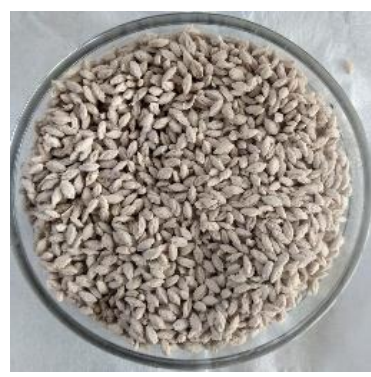

E

Gambar 6. Beras analog dari tepung ubi banggai varietas (A) Harum, (B) Banggai, (C) Pasus, (D) Doso dan (E) Penus

Waktu pemasakan merupakan salah satu parameter mutu fisik yang cukup penting dari beras analog. Tabel 6 menunjukkan waktu pemasakan beras analog. Beras analog dari tepung ubi Doso memiliki waktu pemasakan yang paling singkat (6 menit) sedangkan yang memiliki waktu masak paling lama adalah beras analog dari ubi Banggai dan ubi Penus (9 menit). Waktu pemasakan beras analog dari ubi banggai ini relatif lebih lama jika dibandingkan dengan beras analog dari jagung putih yang berkisar antara 3-4 menit (Noviasari et al. 2013). Waktu pemasakan yang lebih lama ini dapat disebabkan oleh suhu awal gelatinisasi dari ubi banggai yang relatif tinggi yang dicapai oleh waktu yang lebih lama (Tabel 5, Gambar 2). Suhu awal gelatinisasi ubi banggai ini relatif tinggi dibandingkan tepung tapioka (Zhang et al. 2013) atau ubi jalar (Dereje et al. 2020), dan mirip dengan tepung kacang hijau (Zou et al. 2019; Triwitono et al. 2017). Hal tersebut menyebabkan waktu yang dibutuhkan untuk mematangkan beras analog dari ubi banggai lebih lama dibandingkan yang lainnya.

Tabel 6. Bobot seribu butir, densitas kamba, dan waktu pemasakan beras analog ubi banggai

\begin{tabular}{lcccc}
\hline Varietas & $\begin{array}{c}\text { Kadar } \\
\text { Air } \\
(\% \mathbf{b b})\end{array}$ & $\begin{array}{c}\text { Densitas } \\
\text { Kamba } \\
(\mathbf{g} / \mathbf{m L})\end{array}$ & $\begin{array}{c}\text { Bobot } \\
\text { Seribu } \\
\text { Butir }(\mathbf{g})\end{array}$ & $\begin{array}{c}\text { Waktu } \\
\text { Pemasakan } \\
\text { (Menit) }\end{array}$ \\
\hline Ubi Harum & $7.16 \pm$ & $0.56 \pm$ & $15.71 \pm$ & $7.31+0.02^{\mathrm{b}}$ \\
& $0.10^{\mathrm{a}}$ & $0.29^{\mathrm{e}}$ & $0.38^{\mathrm{d}}$ & \\
Ubi & $8.43 \pm$ & $0.49 \pm$ & $11.61 \pm$ & $9.49+0.02^{\mathrm{e}}$ \\
Banggai & $0.09^{\mathrm{a}}$ & $0.19^{\mathrm{b}}$ & $0.37^{\mathrm{b}}$ & \\
Ubi Pasus & $7.39 \pm$ & $0.51 \pm$ & 12.55 & $7.46+0.01^{\mathrm{c}}$ \\
& $0.02^{\mathrm{a}}$ & $0.18^{\mathrm{d}}$ & $\pm 0.31^{\mathrm{c}}$ & \\
Ubi Doso & $7.97 \pm$ & $0.47 \pm$ & $10.10 \pm$ & $6.38+0.00^{\mathrm{a}}$ \\
& $1.58^{\mathrm{a}}$ & $0.35^{\mathrm{a}}$ & $0.40^{\mathrm{a}}$ & \\
Ubi Penus & $7.84 \pm$ & $0.50 \pm$ & $11.66 \pm$ & $9.28+0.03^{\mathrm{a}}$ \\
& $0.17^{\mathrm{a}}$ & $0.35^{\mathrm{c}}$ & $0.25^{\mathrm{b}}$ & \\
\hline
\end{tabular}

Keterangan: Nilai pada kolom yang sama diikuti huruf yang berbeda menunjukkan perbedaan yang nyata $(p<0.05)$

Kadar total fenol beras analog ubi banggai bervariasi, yaitu 39.33-80.50 mg EAG/100 g (Tabel 7). Beras analog dari ubi Harum memiliki total fenol yang tertinggi ( $80.50 \mathrm{mg} \mathrm{EAG/100} \mathrm{g} \mathrm{bk),} \mathrm{sedangkan} \mathrm{dari} \mathrm{ubi}$ Pasus terendah (39.33 mg EAG/100 g bk). Total fenol beras analog dari ubi Harum mengalami penurunan, sedangkan total fenol pada beras analog dari beras analog lainnya relatif tidak mengalami perubahan. Penurunan kadar total fenol dapat disebabkan oleh terjadinya oksidasi senyawa fenolik oleh udara, panas atau aktivitas enzim polyphenol oksidase (PPO) (Queiroza et al. 2011). Walaupun mengalami penurunan, kadar total fenol beras analog ubi Harum masih lebih tinggi dibandingkan beras analog dari bahan baku campuran jagung, sorgum, sagu dan aren (10 EAG mg/100 g) (Budijanto et al. 2017) dan kedelai detam-1 (26.7 EAG mg/100 g (Anindita et al. 2020).

Tabel 7. Kadar air, total fenol dan aktivitas antioksidan beras analog ubi banggai

\begin{tabular}{lcc}
\hline \multicolumn{1}{c}{ Varietas } & $\begin{array}{c}\text { Total Fenol ( } \mathbf{m g} \\
\text { EAG/100 g bk) }\end{array}$ & $\begin{array}{c}\text { Aktivitas Antioksidan } \\
\text { (\% Inhibisi) }\end{array}$ \\
\hline Ubi Harum & $80.50 \pm 0.001^{\mathrm{e}}$ & $70.79 \pm 0.18^{\mathrm{e}}$ \\
Ubi Banggai & $41.51 \pm 0.005^{\mathrm{b}}$ & $48.07 \pm 0.18^{\mathrm{a}}$ \\
Ubi Pasus & $39.33 \pm 0.007^{\mathrm{a}}$ & $64.57 \pm 0.12^{\mathrm{c}}$ \\
Ubi Doso & $56.04 \pm 0.003^{\mathrm{d}}$ & $61.92 \pm 0.72^{\mathrm{b}}$ \\
Ubi Penus & $49.83 \pm 0.009^{\mathrm{c}}$ & $65.86 \pm 0.12^{\mathrm{d}}$ \\
\hline
\end{tabular}

Keterangan: Nilai pada kolom yang sama diikuti huruf yang berbeda menunjukkan perbedaan yang nyata $(p<0.05)$

Kadar total fenol beras analog dari ubi Harum paling tinggi dibandingkan dengan ubi beras analog dari tepung banggai lainnya. Walaupun secara visual ubi Doso memiliki warna ungu paling pekat dibandingkan ubi lainnya, namun kandungan total fenolnya tidak paling tinggi. Hal ini diduga karena senyawa fenolik pada ubi Doso merupakan senyawa fenolik bebas sehingga pada proses pemanasan menjadi lebih mudah rusak, sedangkan senyawa fenolik pada ubi Harum merupakan senyawa fenolik yang terikat yang dalam proses pemanasan membentuk senyawa fenolik bebas.

Beras analog ubi banggai dari kelima varietas menunjukkan aktivitas antioksidan yang tinggi walaupun lebih rendah dibandingkan dalam bentuk tepungnya 
(Tabel 7). Beras analog dari tepung ubi Harum memiliki aktivitas antioksidan yang paling tinggi (70.79\% inhibisi), sedangkan dari tepung ubi Banggai paling rendah (48.07\% inhibisi). Aktivitas antioksidan beras analog dari ubi Harum lebih tinggi dari beras analog campuran tepung gadung, jagung, mocaf dan pewarna angkak (62.10\% inhibisi) (Winarti et al. 2018). Uji korelasi Pearson menunjukkan adanya hubungan yang signifikan $(\mathrm{p}<0.05)$ antara aktivitas antioksidan dan total fenol. Beras analog ubi banggai yang memiliki kandungan total fenol dan aktivitas antioksidan yang cukup tinggi ini berpotensi sebagai sumber pangan fungsional.

\section{KESIMPULAN}

Karakteristik fisikokimia kelima varietas tepung ubi banggai (Harum, Banggai, Pasus, Doso, dan Penus) bervariasi. Ubi banggai mengandung air (12.21-12.74\% bb), abu (2.18-2.75\% bk), protein (10.41-11.68\% bk), lemak (1.05-3.38\%bk), dan karbohidrat (83.22-85.77\% bk). Kelima tepung ubi banggai juga memiliki intensitas warna yang berbeda yang dapat disebabkan kandungan pigmen dari masing-masing ubi yang berbeda. Ubi banggai mengandung pati cukup tinggi (65.38-68.40\% bk) dengan kadar amilosa yang tinggi (38.96-45.09\% bk). Tepung ubi banggai memiliki total fenol berkisar 30.48-116.90 mg EAG/100 g, serta menunjukkan aktivitas antioksidan berdasarkan persen inhibisi antioksidan DPPH (58.71-89.50\%). Profil pasta pati dari kelima ubi banggai cenderung bervariasi. Suhu awal gelatinisasi relatif tinggi $\left(82.5-83.7^{\circ} \mathrm{C}\right)$. Semua tepung banggai mengalami peningkatan viskositas hingga mencapai maksimum dan penurunan viskositas (breakdown) selama fase pemanasan, serta mengalami viskositas setback selama fase pendidinginan. Beras analog ubi banggai dari lima varietas memiliki densitas kamba yang relatif rendah $(0.47-0.56 \mathrm{~g} / \mathrm{mL})$, dan memerlukan waktu pemasakan yang cukup lama (7-9 menit). Beras analog ubi banggai memiliki kadar totar fenol dan aktivitas antioksidan yang berbeda. Kadar total fenol dan aktivitas antioksidan beras analog dari ubi Harum paling tinggi dibandingkan beras analog lainnya.

\section{DAFTAR PUSTAKA}

[AACC] Official Methods of Analysis. 1999. American Association of Cereal Chemist International. $11^{\text {th }}$ Edition.

Adeningsih S, Bahri S, Nurhaeni. 2015. Kajian kadar fenolat dan mutu organoleptik bubur instan dari ubi banggai jenis baku makulolong (Dioscoreabulbifera var celebica bukill) dan baku pukus (Dioscorea alata). Kovalen 1(1): 20-29. DOI: 10.22487/j247753 98.2015.v1.i1.5099.

Agusman, Apriani SNK, Murdinah. 2014. Penggunaan rumput laut (Eucheuma cottonii) pada pembuatan beras analog dari tepung modified cassava flour
(MOCAF). J Pascapanen Bioteknol Perikanan 9(1): 1-10. DOI: 10.15578/jpbkp.v9i1.94.

Aini N, Munarso J, Annisa FS, Jayanthi TT. 2019. Karakteristik beras analog dari tepung jagung-kacang merah mengunakan agar-agar sebagai bahan pengikat. J Penelitian Pascapanen Pertanian 16(1): 1-9. DOI: 10. 21082/jpasca.v16n1.2019.1-9.

Alinnor IJ, Akalezi CO. 2010. Proximate and mineral compositions of Dioscorea rotundata (white yam) and Colocasia esculenta (white cocoyam). Pakistan J Nutr 9(10): 998-1001. DOI: 10.3923/pjn.2010.998. 1001.

Anindita TH, Kusnandar F, Budijanto S. 2020. Sifat fisikokimia dan sensoris beras analog jagung dengan penambahan tepung kedelai. J Teknol Industri Pangan 31(1): 29-37. DOI: 10.6066/jtip.2020.31.1. 29.

[AOAC] Association of Official Analytical Chemistry. 2005. Official Methods of Analysis. Virginia (US).

Ariani LN, Estiasih T, Martati E. 2017. Karakteristik sifat fisiko kimia ubi kayu berbasis kadar sianida. J Teknol Pertanian 18(2): 119-128. DOI: 10.21776/ ub.jtp.2017.018.02.12.

Ariesta K. 2004. Umbi-umbian yang Berjasa yang Terlupa. Simpul Pangan Jogja, Yogyakarta. ISBN: 978-979-359-800-0.

Baba SA, Malik SA. 2015. Determination of total phenolic and flavonoid content, antimicrobial and antioxidant activity of a root extract of Arisaema jacquemontii Blume. J Taibah University for Sci 9(4): 449-454. DOI: 10.1016/j.jtusci.2014.11.001.

Budi FS, Hariyadi P, Budijanto S, dan Syah D. 2013. Teknologi proses ekstrusi untuk membuat beras analog. Pangan 22(3): 263-274.

Budijanto S, Yuliyanti. 2012. Studi persiapan tepung sorgum (Sorghum bicolor L. Moench) dan aplikasinya pada pembuatan beras analog. J Teknol Pertanian 13(3): 177-186.

Budijanto S, Sadek NF, Yuliana ND, Prangdimurti E, Priyosoeryanto BP. 2016. Potensi beras analog sebagai alternatif makanan pokok untuk mencegah penyakit. Pangan 25(1): 61-70.

Budijanto S, Andri YI, Faridah DN, Noviasari S. 2017. Karakter kimia beras analog berbahan dasar jagung, sorgum, dan sagu aren. Agritech 37(4): 402-409. DOI: $10.22146 /$ agritech.10383.

Cornago FD, Rumbaoa RGO, Geronimo IM. 2011. Philippine yam (Dioscorea spp.) tubers phenolic cintent and antioxidanr capacity. Philippine J Sci 140(2): 145-152.

Dereje B, Girma A, Mamo D, Chalchisa T. 2020. Functional properties of sweet potato flour and its role in product development: a review. Int $\mathrm{J}$ Food Prop 23(1): 1639-1662. DOI: 10.1080/10942912. 2020.1818776 . 
Dungir SG, Katja DG, Kamu VS. 2012. Aktivitas antioksidan ekstrak fenolik dari kulit buah manggis (Garcinia mangostana L). J MIPA UNSRAT Online 1(1): 11-15. DOI: 10.35799/jm.1.1.2012.424.

Eduardo M, Svanberg U, Oliveira J. 2013. Effect of cassava flour characteristic on properties of cassavawheat-maize composite bread types. Int J Food Sci 2013: 1-10. DOI: 10.1155/2013/305407.

Fidyasari A, Sari RM, Raharjo SJ. 2017. Identifikasi komponen kimia pada ubi bentul (Colocasia esculenta (L.) Schott) sebagai pangan fungsional. Amerta Nutr 1(1): 14-21. DOI: 10.20473/amnt.v1i1. 2017.14-21.

Hernawan E, Meylani V. 2008. Analisis karakteristik fisikokimia beras putih, beras merah dan beras hitam (Oryza sativa L., Oryza nivara dan Oryza sativa L. indica). J Kesehatan Bakti Tunas Husada 15(1): 7991. DOI: $10.36465 / j k b t h . v 15 i 1.154$.

Jiang Q, Gao W, Li X, Xia Y, Wang H, Wu S, Xiao P. 2012. Characterization of starches isolated from five different Dioscorea L. species. Food Hydocolloids 29(1): 35-41. DOI: 10.1016/j.foodhyd.2012.01.011.

Kong S, Kim D-J, Oh S-K, Choi I-S, Jeong H-S, Lee J. 2012. Black rice as an ingredient in noodles: chemical and functional evaluation. J Food Sci 77(3): 303-307. DOI: 10.1111/j.1750-3841.2011.02590.x.

Kurniasari I, Kusnandar F, Budijanto S. 2020. Karakteristik fisik beras analog instan berbasis tepung jagung dengan penambahan karagenan dan konjak. Agritech 40(1): 64-73. DOI: 10.22146/agritech. 47491.

Kusnandar F, Khonza M, Budijanto S. 2017. Perubahan mutu beras analog jagung selama penyimpanan dan penentuan umur simpannya dengan metode arrhenius. J Mutu Pangan 4(2): 51-58.

Kusnandar F, Mutmainah, M, Muhandri T. 2020. Optimasi proses pembuatan sohun dari pati ubi banggai (Dioscorea alata). J Pangan Agroindustri 8(3): 163174. DOI: 10.21776/ub.jpa.2020.008.03.6.

Marjoni MR, Afrinaldi, Novita AD. 2015. Kandungan total fenol dan aktivitas antioksidan ekstrak air daun kersen (Muntingia calabura L.). J Kedokteran Yarsi 23(3): 187-196.

Martens BMJ, Gerrits WJJ, Bruininx EMAM, Schols HA. 2018. Amylopectin structure and crystallinity explains variation in digestion kinetics of starches across botanic sources in an in vitro pig model. J Anim Sci Biotechnol 9(91): 1-13. DOI: 10.1186/ s40104-018-0303-8.

Mutmainah M. 2020. Karakterisasi Pati Ubi Banggai (Dioscorea alata) dan Aplikasinya Pada Pembuatan Sohun. [Tesis Master]. Bogor: Institut Pertanian Bogor.

Noviasari S, Kusnandar F, Budijanto S. 2013. Pengembangan beras analog dengan memanfaatkan jagung putih. J Teknol Industri Pangan 24(2): 194-200 DOI: 10.6066/jtip.2013.24.2.194.

Noviasari S, Kusnandar F, Setiyono A, Budijanto S. 2015. Beras analog sebagai pangan fungisional dengan indeks glikemik rendah. J Gizi Pangan 10(3): 225-232.

Noviasari S, Widara SS, Budijanto S. 2017. Analogue rice as the vehicle of public nutrition diversity. $\mathrm{J}$ Kesehatan Masy 13(1): 19-27. DOI: 10.15294/ kemas.v13i1.8284.

Nurdjanah S, Nurainy F, Revialdy RD. 2014. Sifat sensori dan fungsional beras analog dari campuran onggok terfermentasi dan ketan hitam. J Teknol Industri Hasil Pertanian 19(1): 28-41.

Queiroza C, da Silva AJR, Lopes MLM, Fialho E, Valente-Mesquita VL. 2011. Polyphenol oxidase activity, phenolic acid composition and browning in cashew apple (Anacardium occidentale, L.) after processing. Food Chem 125(1): 128-132. DOI: 10. 1016/j.foodchem.2010.08.048.

Rasyid MI, Yuliana ND, Budijanto S. 2016. Karakteristik sensori dan fisikokimia beras analog sorghum dengan penambahan rempah campuran. Agritech 36(4): 394-403. DOI: 10.22146/agritech.16762.

Retnaningtyas DA, Putri WDR. 2014. Karakterisasi sifat fisikokimia pati ubi jalar oranye hasil modifikasi perlakuan STPP (lama perendaman dan konsentrasi). J Pangan Agroindustri 2(4): 68-77.

Rodríguez-Miranda J, Delgado-Licon E, Ramírez-Wong B, Solís-Soto A, Vivar-Vera MA, Gómez-Aldapa CA, Medrano-Roldán H. 2012. Effect of moisture, extrusion temperature and screw speed on residence time, specific mechanical energy and psychochemical properties of bean four and soy protein aquaculture feeds. J Anim Prod Adv 2(1): 65-73.

Sani W, Iswadi, Sawingan. 2014. Kandungan pati pada bonggol pisang. Prosiding Seminar Nasional Biologi. Hal, 187-192. Banda Aceh 2014. ISBN: 978602-0898-00-1.

Setiawati NP, Santoso J, Purwaningsih S. 2014. Karakteristik beras tiruan dengan penambahan rumput laut (Eucheunna cottonii) sebagai sumber serat pangan. J Ilmu Teknol Kelautan Tropis 6(1): 197-208. DOI: 10.29244/jitkt.v6i1.8641.

Singh N, Kaur L, Shandhu KS, Kaur J, Nishinari K. 2005. Relationship between physicochemical, morphological, thermal, rheological properties of rice starches. Food Hydrocolloids 20(4): 532-542. DOI: 10.1016/j.foodhyd.2005.05.003.

Srihari S, Lingganingrum FS, Alvina I, Anastasia S. 2016. Rekayasa beras analog berbahan dasar campuran tepung talas, tepung maizena dan ubi jalar. J Teknik Kimia 11(1): 14-19.

Sunyoto M, Andoyo R, Radiani A, Michelle CR. 2016. Kajian sifat fungsional dan amilografi pati ubi jalar (Ipomoea batatas L.) dengan perlakuan suhu dan 
lama waktu heat moisture treatment sebagai bahan sediaan pangan darurat. J Sains Teknol 5(2): 846854. DOI: $10.23887 /$ jst-undiksha.v5i2.8824.

Triwitono P, Marsono Y, Murdiati A, Marseno DW. 2017. Isolasi dan karakterisasi sifat pati kacang hijau (Vigna radiata L.) beberapa varietas lokal Indonesia. Agritech 37(2): 192-198. DOI: 10.22146/ agritech.10659.

Winarti S, Saputro EA. 2013. Karakteristik tepung prebiotik ubi uwi (Dioscorea spp). J Teknik Kimia 8(1): 17-21.

Winarti S, Djajati S, Hidayat R, Jilian L. 2018. Karakteristik dan aktivitas antioksidan beras analog dari tepung komposit (gadung, jagung, mocaf) dengan penambahan pewarna angkak. J Teknol Pangan 12(1): 27-40. DOI: 10.33005/jtp.v12i1.1098.

Whistler RL, BeMiller JN, Paschall EF. 2012. Starch: Chemistry and Technology. Elsevier $3^{\text {rd }}$ Ed. Academic Press, USA. ISBN: 978-012-746-275-2.

Yalindua A. 2014. Potensi Genetik Klon Tanaman Uwi (Dioscorea alata L) Asal Banggai Kepulauan Sebagai Pangan dalam Menunjang Ketahanan Pangan Nasional. [Tesis]. Bogor: Institut Pertanian Bogor.
Yusuf, Sahiri N, Madauna I. 2015. Pertumbuhan dan hasil jenis ubi banggai (Dioscorea spp) pada berbagai pupuk organik. e-J. Agrotekbis 3(5): 555-563.

Zhang X, Qunyi Tong Q, Wenxue Zhu W, Renc F. 2013. Pasting, rheological properties and gelatinization kinetics of tapioca starch with sucrose or glucose. J Food Eng 114(2): 255-261. DOI: 10.10 16/j.jfoodeng. 2012.08.002.

Zhong Y, Zhu H, Liang W, Li X, Liu L, Zhang X, Yue H, Xue J, Liu X, Guo D. 2018. High-amylose starch as a new ingredient to balance nutrition and texture of food. J Cereal Sci 81(2018): 8-14. DOI: 10.1016/ j.jcs. 2018. 02.009.

Zou J, Xu M, Wang R, Li W. 2019. Structural and physicochemical properties of mung bean starch as affected by repeated and continuous annealing and their in vitro digestibility. Int J Food Prop 22(1): 898-910. DOI: 10.1080/10942912.2019.1611601.

JMP-07-21-07-Naskah diterima untuk ditelaah pada 12 Februari 2021. Revisi makalah disetujui untuk dipublikasi pada 2 April 2021. Versi Online: http://journal.ipb.ac.id/ index.php/jmpi 